\title{
For the Love of Children
}

\author{
Practice, Affect, and Subjectivities in Hirata Atsutane's \\ Household
}

Anne Walthall

If grief is one response to the loss of a loved one, then Hirata Atsutane's reaction to the sickness and death of his three-year-old granddaughter from smallpox in 1829 suggests that he indeed loved her: "Atsutane stayed up all night watching over her .... The next day he put her into the bath, but her condition worsened ... . Asking us to keep vigil over her, he put her care in our hands while he shut himself in his study and prayed to the gods. He allowed no one to enter and refused food lest it interrupt his prayers .... She died around three in the afternoon. We made preparations for her funeral, and everyone spent the night at her pillow" (Watanabe 1942: 1059-61). For the twelve days that Fuki suffered, she absorbed her parents' and grandparents' energies and time. They tried everything: medicine, baths, moxa, prayers. After she died, they held a funeral, paid visits to the temple on the appropriate days, distributed steamed buns on the forty-ninth day after her death, commemorated her hundredth-day death anniversary, and remembered her on her death day for the next seven years.

There is a long-running debate in the Western historiography of childhood as to whether parents in the past grieved for their dead children (Cunningham 1998: 1198). Drawing on legal codes, mourning regulations, and other publicly disseminated documents, Shibata Jun argues that in the case of Japan, a transformation in views of children took place between the medieval and early modern periods. Instead of young corpses being placed in sacks and abandoned in the woods or mountains, they were given proper burials, although parents were still warned against the sort of extended mourning that the Hirata family performed for Fuki. Medieval children had been left to grow up on their own; early modern children came to be seen as treasures to be carefully raised and educated. As reasons for this change, Shibata points to political, social, and economic factors such as the 
late seventeenth-century laws of compassion, a society that promoted more stable families with property that could be maintained from one generation to the next, and an intellectual shift from reliance on either Buddhas or gods to reliance on one's own efforts and knowledge (Shibata 2013: esp. 189). In his book on infanticide, Fabian Drixler provides a different explanation. He posits that adherents of True Pure Land Buddhism were much less likely to kill newborn children than those who practiced funerary Buddhism (Drixler 2013). I think that the nativists such as Atsutane and his disciples took a third path: they abhorred infanticide and saw children as gifts from the gods to be cherished and trained for the good of family and nation (Hirano 1983: 93). In short, a number of emotional communities existed in early nineteenth-century Japan, each with its own perception of childhood (Rosenwein 2002: 842). To study even one of them, it is necessary to get below the surface of public pronouncements by examining private records.

My evidence for the place of children in the emotional community of nativists comes from the voluminous collection of documents left by Hirata Atsutane (17761843) and his family in the first two-thirds of the nineteenth century. Children wrote none of them; indeed, it is difficult to find any record of what children thought. Because Atsutane became famous for promoting Japanese exceptionalism based on his understanding of cosmology and the afterlife, his adopted son preserved materials relating to his father and his own efforts to promote his father's teachings. This being a family enterprise, he kept a diary and saved letters that incidentally shed light on the milestones in children's lives, their activities and opportunities as children, and the relations between parents and children and among the children themselves. Although Atsutane is known as a thinker and religious figure, he never forgot his samurai heritage, and he tried to raise his grandchildren as samurai. On the other hand, as a scholar, he shared with other proponents of the Japanese tradition a particular configuration of attitudes toward family and children that at least in their eyes differed from the strands of Chinese thought then prevalent in Japan.

In the status-bound world of early modern Japan, inculcating children with the skills appropriate to their status and performing appropriate childhood rituals attested to and validated a family's position. At the cost of considerable financial strain, the Hirata family tried to match practice to expectations. The family diary provides year-by-year, sometimes day-by-day records of milestones in the lives for boys and girls alike, although it does not always record them consistently. A useful comparison for the norms surrounding the rituals of childhood and attitudes toward children comes from the pen of Tachibana Moribe (1781-1849), Atsutane's close contemporary, like him a nativist scholar, and as such a member of the same emotional community.

Whereas diaries provide information regarding a child's process of maturation, letters speak to the emotional bonds that nativist scholars celebrated as tying the family together, what can be called the affect at play in the family game. Note that here I use "play" and "game" metaphorically to suggest that parents and children 
enjoyed interacting with each other in playful pursuits that demonstrated and deepened their mutual love and affection. Like Moribe's correspondence with his disciple and patron in the weaving center of Kiryū, which addresses the rearing of children, the letters sent by Atsutane and his wife to the family in Edo when he was sent into exile offer tender glimpses of their grandchildren and the children they encountered. Later letters by his grandson Nobutane delimit a different scenario: the difficulty of raising a boy who rejects everyday norms of samurai and scholarly behavior.

Letters also offer occasional glimpses of how men remembered their own childhoods. As he grew older, Atsutane recollected conflicting accounts of how he grew up that, by acknowledging the norms of childrearing practice and calling them into question, shed light on periods of strain in a family history. In a letter to his mother, Nobutane idealized his childhood in a way that reduced it to what it took to make him a man. The various perspectives afforded by these materials make it possible to address questions of what made a child a child and what constituted childhood for early nineteenth-century boys and girls in terms of practice, affect, and subjectivity.

A note on age: In early modern Japan, children were considered to be one year old (sai) at birth and turned another sai at the beginning of each subsequent year, even if they had been born at the end of the twelfth lunar month. Based on their birth dates, I have converted sai for the children I discuss to the Western concept of age. This does not always work, however, when particular sai have meaning. For example, on his fifth sai, a nineteenth-century samurai boy would put on the pleated pants called hakama, a practice still followed by boys in Japan today, though only for the purpose of a shrine visit and formal photograph (see figure 1).

\section{RITUALS AND PRACTICE}

One way to uncover the play of norms versus behavior is to map the patterns of childhood rituals recorded in the Hirata family diary. A caveat: Atsutane kept a diary to remember milestones in his school's development, not in his grandchildren's lives. After he adopted Kanetane as his son-in-law in 1824, he had Kanetane perform this task. Kanetane kept an inconsistent chronicle of his children's lives; many rituals that we can assume the family must have performed go unmarked. Instead he tended to record the children's activities only when they occurred in conjunction with those of adults-going on an excursion, for example. Despite these lacunas, the diary provides a useful introduction to the children and how they grew up.

O-Chō, Atsutane's daughter who married Kanetane, bore seven children, a large number for that era, especially considering the family's straitened finances. As Atsutane's disciple Miyaoi Sadao wrote, "true wealth lies in having many children" (Hirano 1983: 94). A survey of childbirth rates among warrior households done by Isoda Michifumi indicates that the average number of children per household was between two and four, hardly enough to maintain the warrior population. When 


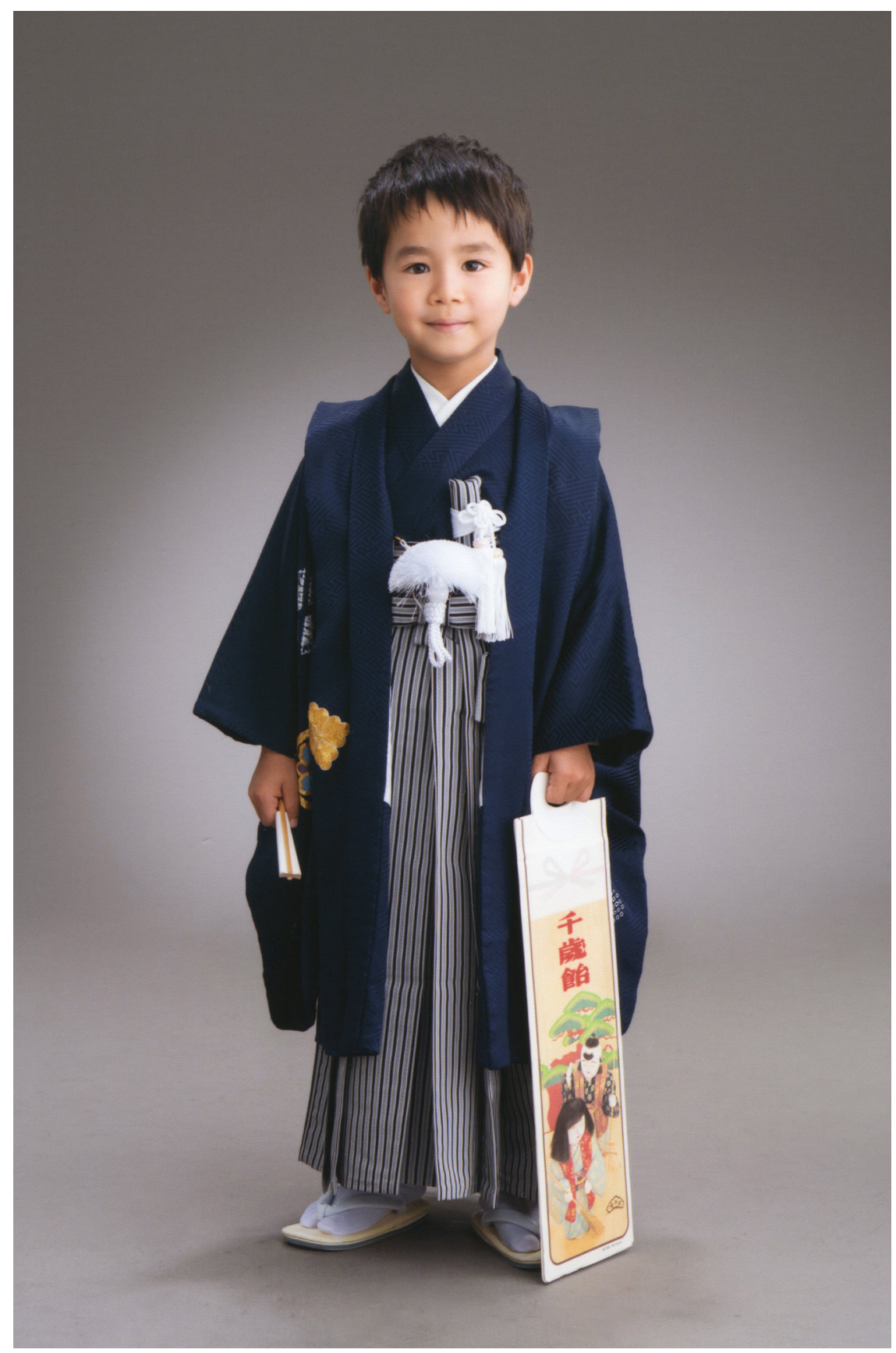

FIGURE 1. Nakai Tomochika dressed in hakama for the celebration of his fifth sai on 15 November 2015. Photo courtesy of Nakai Maki. 
class differences are taken into account, it appears that higher-ranking warriors had 5.13 children apiece; lower-ranking warriors had 3.86 children, in part because the higher ranks married earlier-in the early twenties for men and late teens for women. ${ }^{1}$ Kanetane and O-Chō got a late start: he was twenty-six when they married in 1825; she was twenty. She then spent the next twenty years frequently pregnant and always surrounded by children and infants.

Table 1 below summarizes significant childhood events as they are recorded in the family diary. Note that the lives of the eldest daughter and son are better documented than those of the children born later. This constitutes but one indication that birth order mattered, no matter what the family's status. In the diary kept by a wealthy farm family, the Kitahara in the Ina valley, for example, the father noted his age and that of his eldest son at the beginning of every year, ignoring his other children. When his eldest son was murdered on his way to Kyoto, he then recorded the age of his second son who had under these unfortunate circumstances became his heir (Kitahara-ke monjo). Even though the keepers of the Hirata family diary were more inclusive in their recordkeeping, the possibility remains that some milestones were observed without being recorded, even in the case of the oldest son.

As the first-born son, Nobutane received special attention. Relatives came to celebrate his birth, and the family distributed gifts widely. It celebrated the casting of his horoscope, his first solid meal, and the first time he put on a loincloth. Atsutane started taking Nobutane with him to view the cherry blossoms when Nobutane was only two years old, and a year later they went on an excursion to the mountains. Pleasure trips, usually in the company of his grandparents, continued throughout Nobutane's childhood. When Nobutane was three years old, family friends gave him his first adult-style clothing. He received a new hakama from a different man when he was four in celebration of his fifth sai. To signify his status to strangers, no warrior was supposed to leave his gate without wearing hakama, although by the 1830 s wealthy merchants ceremoniously dressed their five-sai sons in this formal wear as well (in Tosa boys first put on hakama much later; see chapter 2). ${ }^{2}$ Now properly clothed, Nobutane began preparation for his life as a warrior and scholar: his parents took him with them when they paid courtesy calls, one example of how he acquired the social skills that matched his station through imitation. In 1837 , the year he turned nine, the family sent him out on his own to make New Year's visits on its behalf, a practice it continued thereafter.

When children began schooling, their studies varied according to gender, status, and opportunity. Moribe had his son Fuyuteru start writing Japanese and memorizing Chinese at age four (five sai). In Kiryū, the Yoshida daughter and son both began their studies at the local temple school some months before their seventh birthday, once they had turned $8 \mathrm{sai}$, the age at which most children started schooling (Shibata 2013: 81, 131). He also attended a private academy to study Chinese whereas she practiced the koto. In the year Nobutane turned six, he began 


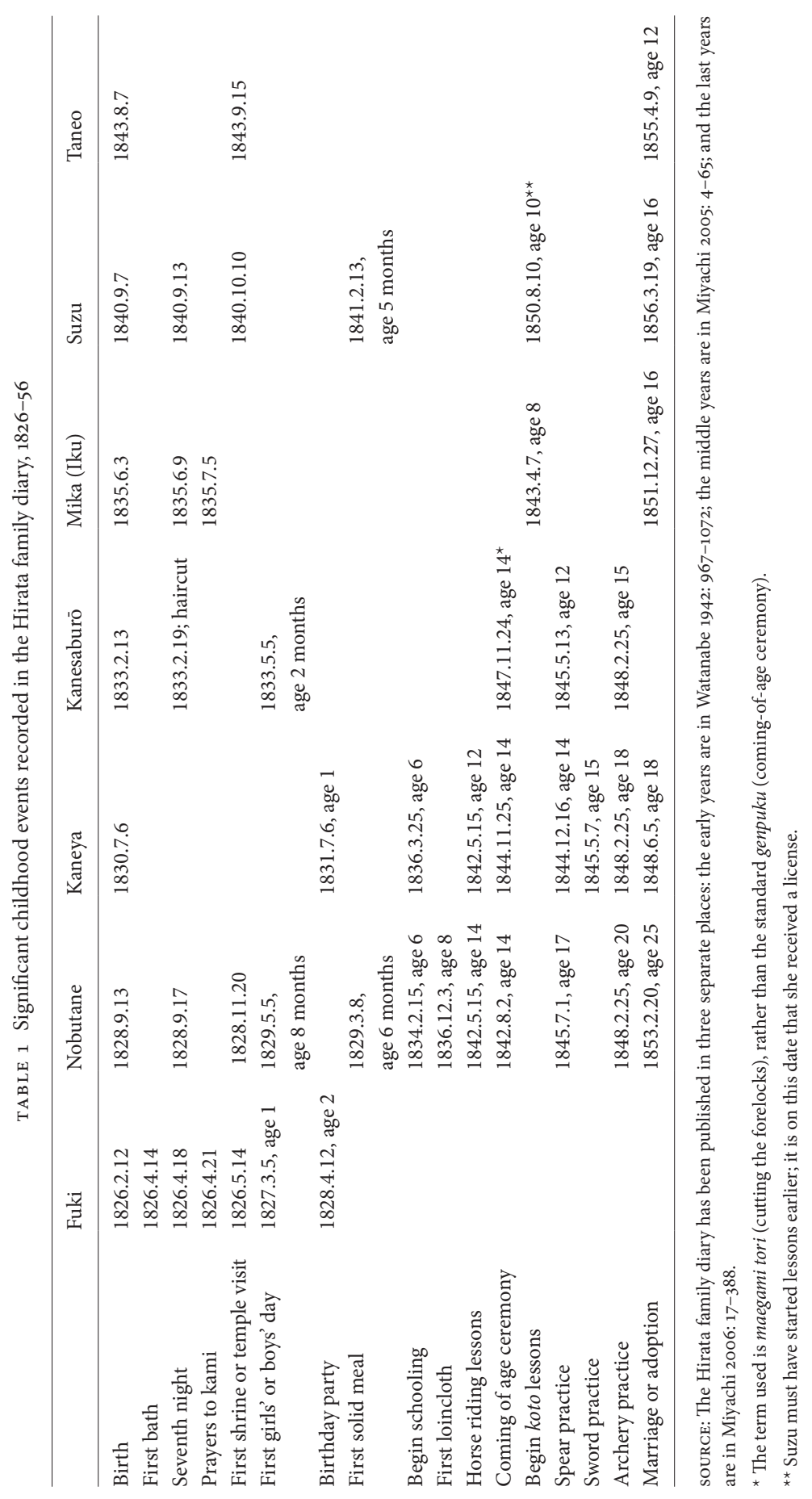


to learn to read and write, and the next year read a text written by Atsutane. In a later letter from Akita, Atsutane noted that "all of the warriors here right down to the children know at least the Four Books and Five Classics," the fundamental texts in the Chinese tradition (Watanabe 1942: 574). We can assume that Atsutane's male grandchildren were equally well educated, even though like Moribe, Atsutane lauded the superiority of all things Japanese over the Chinese.

Although the Hirata family had warrior pretensions, its lack of official standing during the years while Nobutane was growing up curtailed his opportunities. The point of being a warrior was to serve a lord, but until Atsutane received status, rank, and salary from Akita in 1842, the Hirata had no lord to serve. This meant that Nobutane did not have his first audience with a lord until after he had gone through his coming-of-age ceremony. At one point Atsutane suggested that it be postponed in order for Nobutane to meet the requirements for being a page. Some months later, he proposed adding two years to Nobutane's age to quality him for a larger stipend (Nakagawa 2014: 71). Most warrior boys had their first audience between the ages of seven and nine, and those of high enough status then became the lord's pages and wore a long-sleeved kimono. At $12.5 \mathrm{sai}$, they performed the sleeve-shortening ceremony and become apprentices; at 14.5 sai they cut their forelocks and came of age (Isoda 2013: 183-84). Most began practice in the martial arts well before that time. In the kabuki play Tweezers (Kenuki), for example, Hata Hidetarō, the boy sent to keep the lecherous hero Kumedera Danjō company, announces that he has studied spearmanship and archery. Hearing that Hidetarō has not yet learned to ride a horse, Danjo announces that "the way of horse and bow is what the warrior must learn first of all." When he offers to teach the boy how to ride and demonstrates what he intends, Hidetarō calls him lewd and runs off (Kokuritsu gekijo 2012: 15). Although Nobutane studied the martial arts, he did so as a latecomer; for him, textual studies came first. In his case, the norms that governed samurai upbringing mattered less than family circumstances in determining what and when children learned.

The family's changing circumstances had an effect on the younger sons. Once Atsutane became an official member of the Akita retainer band, Kaneya began horseback riding and Kanesaburō started spear practice, both before their respective coming-of-age ceremonies. When Kanetane left for Akita in 1843, he took Kaneya with him. To the boy's delight, he rode out of Edo on horseback. In the meantime Kanesaburō stepped in to act as messenger while his older brother Nobutane took over dealing with publishing issues, getting the house cleaned, and doing the shopping.

The two younger daughters receive scant attention in the diary. In part this is because they did not accompany their parents or grandparents on formal occasions; they went out only when visiting a shrine or temple or going on pleasure excursions. Starting when she was six years old Mika went to stay with relatives for days at a time, perhaps to entertain those without children of their own or perhaps 
to become acquainted with the ways of other households in preparation for the day when she would leave her natal family in marriage. Suzu followed suit, going with either her mother or maternal grandmother to visit her other grandmother, Kanetane's mother. The grandparents bought dolls for the doll festival two days before it is held, but the diary makes no mention of the festival itself. The girls went shopping with relatives; they attended a koto concert; they enjoyed going to kabuki with their mother and older brothers. Mika even went to Ueno with her mother and the two younger sons to watch the arrival of a Ryukyuan emissary. It is recorded that she once received a box of sweets from her uncle, Kanetane's brother, in a suggestion that who was important was not the recipient, but the giver and what mattered were the continuing ties between the two families.

The diary notes children's activities largely in relation to those performed by adults; only when children get sick do they become visible on their own. We have already seen how Atsutane responded when Fuki died of smallpox. Her cry of pain- "Scary things have come, they've come again, oh, go away"-constitutes the sole instance when the diary records a child's voice (Watanabe 1942: 1060).

The other children too suffered from a variety of diseases. Although they all caught smallpox, none of the rest of them died. Instead they went on to suffer from measles, chickenpox, fevers, influenza, dysentery, and mumps. Parasites made them sick as well. In one of Atsutane's letters from Akita, he writes: "I am delighted to hear that the four children have been wormed. I prayed a long time, and let me tell you about worms. Watanabe Zenzō's granddaughter, at least eight years old, became peevish, cried burning tears constantly, and ate all sorts of things, ashes, dirt, incense, a difficult situation. It was too much to bear so I had her take some of that worm-expelling medicine. The next day she voided six big worms, and by the following day, she was all right" (Watanabe 1942: 547).

In an age when childhood diseases could easily prove fatal, it is not surprising that they so often appear in the Hirata family diary. When disease attacked the heir, it threatened the family's social and economic survival. Fuki's case shows how it also threatened the fabric of the family as an affective unit. Children were at their most vulnerable when they embodied disease; that is, when they brought to the surface concerns for their welfare that otherwise went unrecorded.

The Hirata family diary does not provide a thorough accounting of children's lives. Both Mika and Suzu learned to read and write, but there is no mention of when they started to study. No ceremonies marked their entry into adulthood. The only person to garner even less attention is the youngest brother, Taneo, born just a couple of months before Atsutane died in Akita. Without his famous grandfather to take him on excursions, he easily escapes notice. But because his next older brother, Kanesaburō, also receives less mention than the two older boys, it is clear that birth order as well as gender played an important role in determining the amount of recordkeeping expended on children that the family deemed necessary for its identity. 
Gender and birth order inequality also permeated treatises on childhood. In contrast to texts written for girls-for example, A Treasure House of Greater Learning for Women (Onna Daigaku takara bako) - those addressed to men took the generic term "child" to mean boys. In his essay on household management, the village headman and Hirata disciple Miyaoi Sadao discussed how to raise a good child, one who could achieve success in this world, and he praised the virtues of loyalty and filial piety above all others (Hirano 1983: 93). In addition to Atsutane and Chinese philosophers, he quoted the eighteenth-century author Hayashi Shihei, who wrote a set of instructions for fathers and older brothers. Hayashi's aim was to help fathers achieve their goal of raising intelligent and good children (boys), a goal to be achieved by having the child internalize the four literary virtues-filial piety, obedience, loyalty, sincerity - and the four martial virtuesbravery, righteousness, honor, integrity. Although women might aspire to these virtues in an emergency, such attributes were usually gendered male. The role of the elder brother was to love and educate his younger brothers, treat them with compassion and kindness, and live in harmony with them (Yamazumi and Nakae 1983: 65-66). Neither Miyaoi nor Hayashi discussed a father's or an elder brother's role in raising girls.

\section{FOR THE LOVE OF CHILDREN}

Aside from its depiction of Fuki's death, the Hirata family diary reveals nothing about the emotional communication between parent and child. For a different perspective, let us turn to the letters written by Atsutane and his wife, Orise, when the shogunate exiled him in 1841 for unspecified reasons likely having to do with his criticism of Confucian studies. The couple went to Akita, where Atsutane had been born, and where he eventually gained warrior status and a small stipend. Addressed to the family back in Edo, the letters speak to the strong bonds between grandparents and grandchildren: the affect at play in the family game.

In his letters Atsutane often harped on themes of longing for the grandchildren. "Oh, I want to see the children. It's all the two of us talk about," Atsutane wrote in his first letter dated 1841.1.7. In a postscript he lamented, "In my dream last night I was delighted that you and [servant] Ichitarō brought Kaneya to me, but alas, it was only a dream" (Watanabe 1942: 533). This was a dream he had more than once. "On the night of the twenty-seventh of last month, one by one Suzu and the others came flying through the sky. I sat them on my lap and pressed my cheek against theirs .... Y You and Chō came afterwards and saying that it was getting late, snatched them away. I woke, asked my wife if she had seen them, and realized it was a dream" (Watanabe 1942: 588). While still on his journey, he wrote a poem describing how thoughts of his grandchildren unmanned him (Watanabe 1942: 542): 


$\begin{array}{ll}\text { masurao to } & \text { Even I, } \\ \text { takebishi ware mo } & \text { a manly man } \\ \text { ie ni aru } & \text { when I remember } \\ \text { marashi omoeba } & \text { the grandchildren at home } \\ \text { namida gumashi mo } & \text { cannot hold back my tears. }\end{array}$

Whether or not Atsutane actually cried, here he used tears as a textual representation of grief. As Gary Ebersole has pointed out, poems "present evidence of what was considered to be the appropriate affective (and verbal) display for a sensitive and cultivated person" (Ebersole 2008: 76). It is also important to pay due attention to the context. Atsutane never recorded having shed tears at the thought of separation from his daughter. Instead his tears were always for his grandchildren, the appropriate object of longing for an old man.

Although the bulk of Atsutane's letters concerned his own affairs, he regularly commented on his grandsons. He wanted reports on how they were doing with their studies, and he exclaimed: "Nothing makes me happier than that Nobutane and Kaneya like books" (Watanabe 1942: 620). As he pointed out: "I've heard that there is inevitably a test before employment whereby officials appear at the domain school to have the [candidate] read from the Four Books [of Chinese classics]. It's not a question of reading them all, but of opening pages here and there to be read. You need to make careful inquiries of Hirayama Keisuke so that Nobutane does not embarrass himself" (Watanabe 1942: 661-62). Since Nobutane lived in Edo, he did not attend the domain school. Nonetheless, Atsutane worried that he might face some kind of test, even in Edo, and sent this warning that the family should be prepared. He also urged Nobutane and Kaneya to be diligent in the martial arts. On the other hand, it appeared that Kanesaburō did not like to read. Atsutane suggested drawing him in by starting with a picture book about warriors. "He needs to be able to do the literary and martial arts, and I want him to like being useful in all things" (Watanabe 1942: 693).

Atsutane's letters also display attitudes toward childhood that fly in the face of conclusions reached by European students of family strategy. These scholars argue that the less children contributed to the household economy, because schooling had become increasingly important, the more they became "emotionally priceless" (Cunningham 1998: 1203). In the Hirata family of scholars, the male children were carefully schooled, letters demonstrate that they were loved, but they also participated in household enterprises. They made copies of texts for Atsutane (for example, five volumes about the domain's local customs) and copied Atsutane's texts that could then be sold to disciples or presented to patrons (Watanabe 1942: 646,692 ). While still a student, Moribe's son too helped annotate manuscripts for publication and taught memorization of Chinese texts to pupils from the countryside (Takai 1991: 211, 219). As was typical for most children before modern times, they earned their keep, but in ways that contributed to their education. 
Atsutane's letters show that he loved all of his grandchildren, but his chief concern was that his grandsons grow up well. He made scant mention of his granddaughters except for the baby Suzu. Instead, like the men who wrote solely about issues related to boys when they addressed the subject of childrearing, he focused his attention on the serious side of childhood-the studies and training required of a samurai/scholar boy.

Although Orise too wanted her grandsons to excel in their studies, in her letters she commented on a greater range of their activities and discussed issues pertinent to her granddaughters and the children she got to know in Akita. She lamented her separation from the grandchildren; for her nothing was more painful than the thought of not being able to see them for the next year or so, and she claimed to dream about them every night. If Atsutane could not return to Edo, then the best thing would be for Kaneya, no, the entire family, to join them. She was often ill during exile, but both she and Atsutane thought that if she had the grandchildren around her, she would quickly recover.

Like Atsutane, Orise emphasized the importance of having the children learn to take responsibility for contributing to the family enterprise, but for her "the children" meant girls as well as boys. "Ichitarō told us in detail about how Nobutane and Kaneya help out when you serve the gods, and that affected us very much. We're delighted that the two of them are such a help to you" (Yokoyama 2012: 19). Being of help was expected of children; Orise remarked at one point that "even though it's too bad that Nobutane is kept busy helping you, it's important to have him put up with it a little now so that he can become a fine young heir of use to his grandfather" (Yokoyama 2012: 47). Orise also praised O-Chōs childrearing skills: "I'm impressed that you're putting the children to work by having them compete with each other. If you do like this and send them on errands, none of them will end up lazy. Your disciplining of them is excellent" (Yokoyama 2012: 42). Orise was gratified to learn that the older granddaughter Mika had done a fine job of sewing cotton underwear, and that even at the age of seven, she had become such a help to her mother. Perhaps next year she could make underwear for Orise and Atsutane (Yokoyama 2012: 77).

The only child who had no responsibilities and the freedom to do as she pleased was baby Suzu. For her first doll's day, her mother dressed her in a loose robe and made a doll for her. Orise thought she must have looked really cute. Three months later Suzu got a long-sleeved kimono, and Orise mentioned that Atsutane was delighted that her complexion was whiter than that of Mika's friends in the neighborhood. As she got older, Suzu became increasingly mobile: "It's early for Suzu to be crawling around with her rump in the air, standing by holding onto furniture, and pulling candy out of the drawer on the hibachi to eat all by herself. How adorable" (Yokoyama 2012: 22, 46, 54).

The lack of restraints on Suzu's freedom probably did not last long. Just a few months later, on 1841.10.21, Orise warned O-Chō: "Suzu will soon become three sai [by Western count, she was barely over a year old], and what happens 
to her hereafter will be very important. You must be mindful to take good care of her because [character] will inevitably come out later. Even though you have a nursemaid, because she's your child, you must be the one to raise her" (Yokoyama 2012: 76).

At the age of six by the Western calendar, Mika was already learning how to act and dress like the daughter of a samurai/scholar. Along with her older brothers, she wrote letters to her grandparents and copied texts. Orise was delighted at her clear handwriting. At the New Year, Mika made decorated string balls and shuttlecocks to entertain her siblings. According to the family diary, she had a koto teacher; Orise's letters indicate that she also learned singing and samisen, a popular instrument that was sometimes considered more suitable to members of the commoner classes than the koto. Orise commented on Mika's clothes; she obsessed over the procurement of a hairpin. At the beginning of 1842, Orise wrote a New Year's greeting addressed to the women of the family-O-Chō, Mika, and Suzu. In the same envelope was a letter addressed to Mika alone:

I've read your charming and detailed letter over and over, more times than I can count .... I'd like to send you some sort of toys to play with, but here I'm not allowed to go out shopping .... I've thought of a few things that are really boring and sent them to you just for the sake of having something to send. I've heard that you'd taken them out any number of times to play with. The next time I'll send you lots of much better things, so please be patient.

You must have looked adorable at New Year's in your striped crepe kimono tied with a black obi and obi tie with cute hairpins in your hair.

Your white face powder must have been skillfully applied for the New Year. Your grandfather and I have been talking about it.

I've put your letter in the drawer to my sewing kit, I read it numerous times every day, and I cry tears of joy.

As usual Orise could not resist a few words of admonishment:

Please treat your older brothers well and be charming to everyone as you get older....

Please be careful when you play not to fall in the pond and not to injure yourself. Please get along with everyone when you play. Your mother must be busy, but please do not take a break from practicing samisen and singing. I'll want to hear what you've done when we meet again. (Yamaguchi 2014: 109-10)

This missive displays the strong affective bonds between grandmother and granddaughter and how each strove to maintain them. In the private, domestic sphere that constituted Orise's chief venue, women typically took the lead in maintaining relations, performing what has been called kin work. Orise and Mika probably wrote directly to each other on other occasions as well, but this is the only missive to have survived. Mika must have written a letter describing her New Year's activities, with whom she played, and her musical studies. In return Orise sent 
her presents and promised better ones, offered advice on how to behave around other people, and conveyed her love for her granddaughter by recounting how she treasured her letter.

Orise often spoke for Atsutane in expressing his love for his grandchildren. While they were on the road to Akita, they became acquainted with an Akita domain retainer and his eleven-year-old son, Sutematsu, who was just the same age as Kaneya, which made him particularly attractive to Atsutane. Sutematsu diverted the couple with his antics, helped Orise pick edible plants in the mountains, and escorted them to a house party just before their departure. That night Atsutane announced that he wanted to sleep with Sutematsu in his arms. The boy replied, "Alright," and went to sleep. "He really is a cute kid," was Atsutane's comment (Yokoyama 2012: 28). This anecdote reminds us of the custom for elders to have a young person share their bed; in fact Orise mentioned that she longed for the day when they would all be together and Kanesaburō would quietly creep up to her back and take care of her (Yokoyama 2012: 11). Children warmed the bedding; they provided close and intimate companionship.

Orise's letters also give glimpses of the relations at play between children. On the one hand, she warned the brothers not to quarrel or fight with each other; on the other, in a statement addressed directly to the four older children, she instructed them to get along and praised them for doing so: "Your grandfather, Ichita[rō], and I talk daily about how the four of you are in good health and get along so well when you play. Be sure to be well behaved and I'll bring you lots of good presents next year. Wait for us, don't cause trouble for your father and mother, and don't get injured. You must treat Mika with affection and get along well together. You must also treat Suzu with affection. Once you get older, please come here" (Yokoyama 2012: 3). And what games did they play? Flying kites and spinning tops, at least for the boys. As for getting along, Orise warned: "Please tell Kaneya not to drop Suzu in the pond when he is carrying her on his back. I'm really worried about that" (Yokoyama 2012: 55).

It is well known that until recent times, children took care of other children to free their parents for productive work. Indeed, children often spent more time overseen by their siblings than by adults. In the Meiji period, taking care of infants became a strictly female occupation, as illustrated in figure 2, a carefully posed postcard from 1912 (Tamanoi 1991: 800). Orise's caution to Kaneya suggests that in the 1840 , gender mattered less than birth order and age, a finding that replicates Kathleen Uno's study of Tokugawa-period childcare (Uno 1987: 31). Kaneya was ten years Suzu's senior, whereas the age gap between Mika and Suzu was only five years, too narrow for Mika to have been able to carry her around as the girl in this postcard is doing. In fact Mika had a nursemaid herself, one who came from outside the family. Nobutane was even older, but he was taking on adult responsibilities. That left Kaneya, who did not, apparently, relish this chore. 


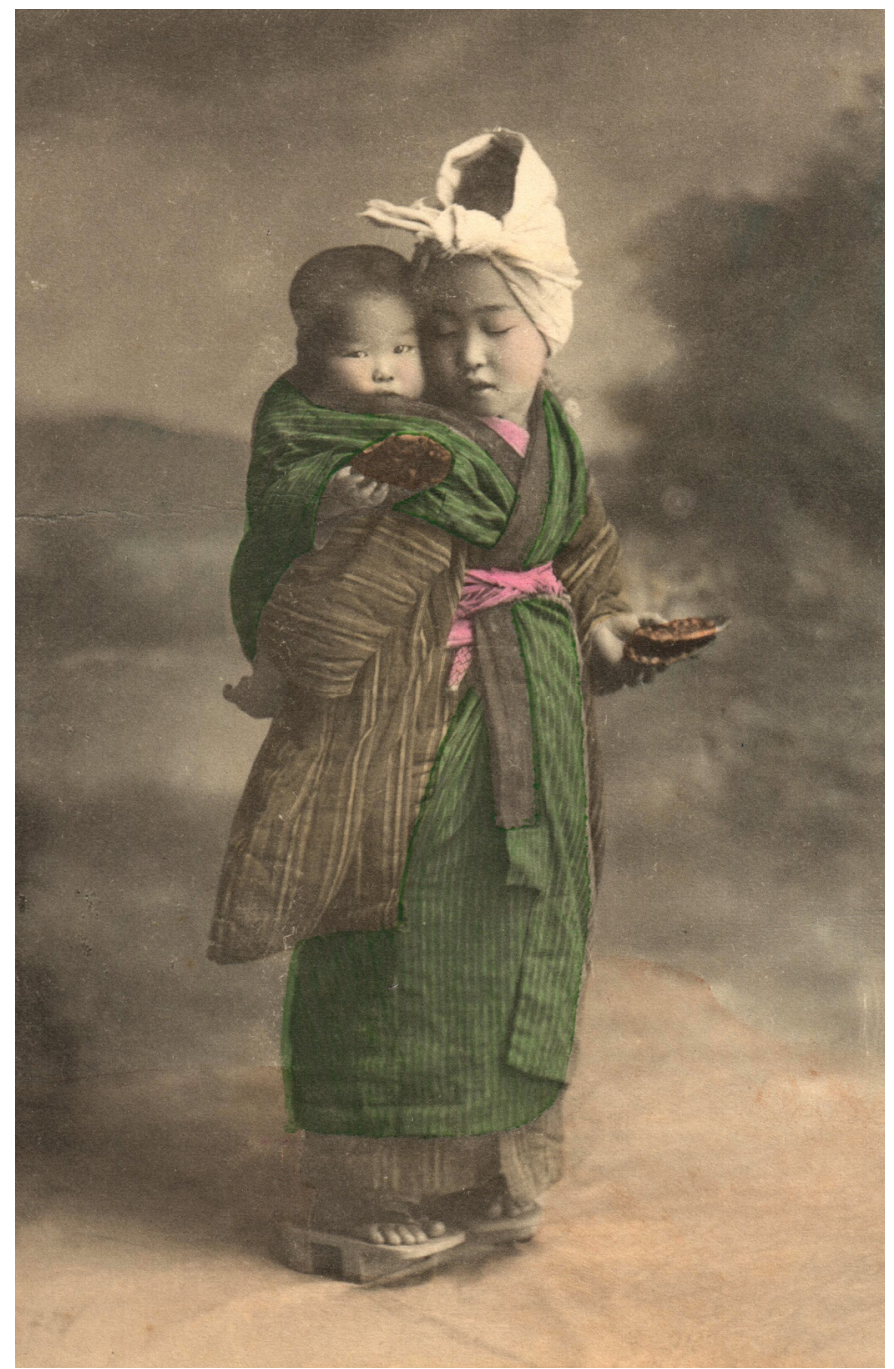

FIGURE 2. Young girl feeding a rice cracker to her infant charge, 1912. Courtesy of the author.

Many years later, when Nobutane found himself in the position of trying to raise a child, a different affect came into play. There were two complications: First, the boy, Shin'ichirō, was one Nobutane was trying to decide whether to adopt. Second, Shin'ichirō spent months living with Kanetane in Kyoto before Nobutane was settled enough in Tokyo to have the boy live with him. 
Thanks to the system of attendance on the shogun in the Tokugawa period that took samurai men away from home for months or years at a time, raising a child at a distance had happened frequently. What mattered to Nobutane, however, was the difficulty of establishing an affective bond between Shin'ichirō and himself. As he wrote to his sister in 1870 , "I want somehow to get Shin'ichirō under my own roof. This is because if I don't do so, I don't think I'll be able to consider him to be my child" (Shokan 15-38-12-1). Or again in a letter to his parents: "If I don't raise him myself, I'll not be able to think of him as my son" (Miyachi 2006: 471). To his parents he acknowledged that for them to have grandchildren with them provided consolation in difficult times. "If I summon all of the children, you'll be lonely, but if I don't bring them here, I can't raise them myself." Even if the other children stayed in Kyoto, he wanted to put Shin'ichirō on trial to see if he could be of use (Miyachi 2005: 99, 102, 103).

Once Nobutane had Shin'ichirō under his roof, he discovered that the boy resisted playing by the rules of the game. On the journey from Kyoto, Shin'ichiro had thrown his books in the river, peed in public in Odawara, stopped studying, and generally tried his tutor's patience (Shokan 15-38-14-3). Once in Edo, he played all sorts of tricks; he bit the steward; he threw stones at a servant. He took money from Nobutane's desk and went to buy candy at the teashop outside the gate; worse, he did not wear his sword when he did so. Nobutane had received sweets for his work as the emperor's tutor; Shin'ichirō rudely helped himself to them. The servants were supposed to watch him, but one day he took advantage of their inattention, removed his hakama, and with just a dagger went several blocks away to a bookstore all by himself. "From one day to the next, someone drags out the struggling Shin'ichirō, each short of breath, to make a complaint." Nobutane discussed his problems with an old friend who just knit his brow and sighed. "He said that sort of thing goes on all the time at his house and at Hashizume's with their sons and in other households as well. Scolding does no good" (Miyachi 2006: $484,485,492)$.

In contrast to the good children praised in the letters from Atsutane and Orise, Shin'ichirō played the bad boy, much like the boys deplored by monks in chapter 1. Not only did he act like a common thief, he also violated the norms of samurai dress and behavior, at least according to Nobutane's ideas regarding appropriate conduct. His tutor admitted that while Shin'ichirō had an open-hearted disposition, he was wild and often resorted to violence (Shokan 15-38-16). Since the tutor was responsible for Shin'ichirō's conduct as well as his studies, this was mortifying.

Shin'ichirōs actions remind us that not all children were paragons of virtue; some centered their attention on themselves. Moribe lamented that when Ito, his Kiryū disciple's daughter, came to stay with him, "because she's been raised too much as she pleases, she does what she wishes, and she's stubborn and obstinate." "The other day when we showed her the roll of cloth for a summer robe that you'd sent, she replied, 'Am I supposed to wear that?' and flung it away." What shocked 
Moribe's household was not just her display of ingratitude and ill temper, but also her use of "ore", a man's term, for "I" (Takahashi 1991: 383). Despite her display of selfishness, Moribe remained fond of her and treated her as one of the family.

Just as the Hirata family diary contains information related to children only incidentally, the same is true for the letters written by Atsutane, Orise, and Nobutane. Nonetheless, Orise and Atsutane spared a few words for the grandchildren in almost every message, and so too did Nobutane regarding his potential adopted son. In some cases, these words repeat normative expressions of feeling, but they sometimes provide a glimpse of what the children had been doing. To the extent that they refer to concrete, singular actions, they convey a sense of the bonds of affection that held families together and point to the emotional as well as economic value children brought to the family game, what Frühstück calls emotional capital (see chapter 9).

Affection for children constitutes a powerful if overlooked motif in early nineteenth-century nativist writings. This can be seen as arising from the determination to privilege the emotions as the basis for relations between people in contrast to the suspicious rationality of Chinese thought. As the eighteenth progenitor of nativist studies, Motoori Norinaga (1730-1801), famously declared, Japanese values were superior to Chinese because they were based on the spontaneity of human feeling (Nakamura 1991: 39). Thus Moribe claimed that nothing was more important for the family than the love between husband and wife. He also stated that "filial piety should come from within the child in response to the parents' love; it should not be coerced by outside dictates [as in China]" (Takai 1991: 262, 266).

\section{SUBJECTIVE VISIONS OF CHILDHOOD}

It is difficult to know what children thought of their upbringing. Even when people look back on their childhood, they do so from an adult perspective that abridges and distorts their past. In the case of Atsutane, we have various accounts of his early years in Akita. They contradict each other and remind us that the staging of an authentic experience is contingent on a host of factors not always knowable to the individual himself. Nobutane also wrote a short statement reflecting on his upbringing; it too must be read within the context of the larger argument he was trying to make.

Atsutane's official biography, composed by his adopted son Kanetane, takes a positive approach to his early years. Born on 1776.8.24 to a middle-ranking samurai family, Atsutane was the fourth of five boys. He also had three sisters. One month after his birth, his family shaved off his birth hair and preserved it, an indication that it performed the ceremonies for him that marked a child's early years. When he was eight sai, the appropriate age to begin education, his father sent him to study with the domain's Confucian instructor. He also trained in the martial arts, learning how to use the bow, spear, and sword. Right before he went through 
his coming-of-age ceremony, his father said to him, "If Confucius had been born in this country, he would not have studied Chinese things but rather those of this country. I have not yet studied them, but I really want to have the things of this country known." Atsutane later absconded from the domain at age nineteen because he did not get along with his stepmother (Ueda 1978: 1115).

In this version of Atsutane's life, he had the conventional childhood of a samurai boy. His family made sure that he got an education, and he learned both the literary and martial arts. His father even encouraged him to excel in his chosen field. Truncated though this account is, it still allows us to see a social construction of childhood that puts the child's development first.

Atsutane recorded other accounts of his childhood that conflict with the official version. In a letter he wrote to Kanetane on 1842.11.2, he stated: "When I look back on my childhood, I remember that I was raised neither by my mother nor my father from the day I was born." In a longer fragment that may have once been attached to this letter, he described how he had been denied the warmth of family affection from birth, symbolized by his distance from the heat of the hearth:

I was treated as a foster child and raised in misery to the age of six in the house of a poor foot soldier. I had gotten accustomed to the place when my wet nurse's husband died, and I was sent back home. There my parents and siblings maltreated me and always spoke to me in the cruelest, most outrageous fashion. From age eight to eleven, I was given over to a wealthy acupuncturist named Sakurai Shūkyū. Just when I realized that I did not want to become a crummy doctor, a child was born in my adoptive family, and I was sent back home. Thereafter I cooked the rice, did the cleaning, yanked weeds, and minced along like a messenger carrying shit. While saying we can live in harmony as siblings, my brothers treated me hatefully. They struck me, and they beat me. I never ceased having a bruised head ... I was further disliked because I have a birthmark on my face that was said to be a sign that I would kill my brothers and take the house by force. Once when I was suffering from an acute illness for at least a year in that cold country, my oldest brother gave me a meager set of nightclothes for the first time. After he died I never received any nightclothes. By selling some handicrafts I got a little money, and with that I bought beggar's rags to wrap myself in at night. In that way I endured the extreme cold of winter, and I never tried to approach the heat of the fire even once. Even though I feared my parents and tried to avoid them, I never felt that I hated them (Itō 1973: 19-20).

According to this account, which may suffer from exaggeration, his parents did not even bother to have a coming-of-age ceremony performed for him. Having been treated so harshly and as proof that he had no intention of killing his brothers, he ran away to Edo.

Atsutane's parents had an unusually large number of children, and it is possible that his was one more birth than they could afford. In Europe as well, families would seek outside help in caring for excess children at "pressure points in the family life cycle" (Cunningham 1998: 1204). Sometimes the intent was to reclaim 
the child when conditions improved; sometimes the child was abandoned. That Atsutane was never reclaimed nor completely jettisoned suggests that the emotional value assigned to him by his parents fluctuated at a fairly low level.

Atsutane left a number of accounts of his childhood that emphasized how coldly his family had treated him. One scholar has even declared that Atsutane's upbringing warped his personality and contributed to the excesses in his later writings (Kamata 2000). While it is likely that he was more emotionally deprived than his grandchildren, it is also possible that his recollections, put on paper during his exile, contained a tinge of bitterness at being forced back to the town he had thought never to see again. He may also have wanted to heighten the contrast between a good childhood-living with loving parents and receiving an education-with his own in order to emphasize the obstacles he had overcome in making a name for himself.

Having experienced what was to all appearances a nurturing childhood environment, Nobutane's subjective recollections of his upbringing took a different perspective. In a letter to his mother, he wrote: "When I look at the person I have become now, I have to say that all the hardships I went through a long time ago have proved their worth. For that reason, I want you to please, please force hardships on Shin'ichirō so that he becomes a splendid person" (Miyachi 2005: 110). Forgotten are the games Nobutane played as a child, his excursions with his grandparents to view the cherry blossoms, and the celebrations for boys' day. Instead he remembers that he suffered, and that the suffering made him a better person.

\section{CONCLUSION}

Any discussion of childrearing practices, attitudes toward children, and childhood experiences in early modern Japan has to take their diversity into account. Samurai and scholars such as Hirata Atsutane, Miyaoi Sadao, and Tachibana Moribe placed great emphasis on book learning, even for girls. They articulated a vision of childhood development that would lead to the creation of a productive adult-someone of use not only to the family but also to the larger society and, in the case of Miyaoi, the imperial realm. It is easy to assume that most parents would have agreed with this goal, even if they stated it differently or employed different means.

And what about the impact of affect on the family game? One justification for sending children away from home to live and work was that tenderhearted parents spoiled their children, as Moribe hinted in his letter commenting on Ito's selfcentered behavior. ${ }^{3}$ Judging from Nobutane's recollections, indulging children was not a problem in the Hirata house. On this point as well, historians need to account for a diversity of attitudes and behavior. In his analysis of the practice of infanticide, Fabian Drixler demonstrates that it occurred more frequently in certain regions than in others and traces this variation to differences in religious belief. In a 
similar fashion, I have posited the existence of various "emotional communities""social groups that adhere to the same valuation of emotions and how they should be expressed" (Plamper 2010: 253; the term was coined by Barbara Rosenwein). The community at issue here was centered on the teachings first exemplified by Motoori Norinaga and then expanded and complicated by later nativist scholars such as Atsutane, Moribe, Miyaoi, and others. In valorizing Japanese sensibility over Chinese inflected rationality, this community encouraged written displays of familial affection. Children were important not just because they ensured the family's continuity but because as a concrete representation of the parents' love and affection, they tied the family together.

\section{NOTES}

1. Isoda 2013: 178, 190, 193. Isoda bases his conclusions on an analysis of Utsunomiya domain records.

2. Isoda 2013: 79; Takahashi 1991: 387. One of Orise's letters from Akita asks that O-Chō send a secondhand child's summer hakama, because Atsutane's great-nephew, Ōwada Shöji's five-sai son, did not have one, the Ōwada being really poor (Yokoyama 2012: 47, 58).

3. For similar sentiments, see Walthall 1991: 45.

\section{BIBLIOGRAPHY}

Note: Unless noted otherwise the place of publication for Japanese books is Tokyo.

Cunningham, Hugh. 1998. "Review Essay: Histories of Childhood." American Historical Review 103(4): 1195-1208.

Drixler, Fabian F. 2013. Mabiki: Infanticide and Population Growth in Eastern Japan, 16601950. Berkeley: University of California Press.

Ebersole, Gary L. 2008. "Japanese Religions." In The Oxford Handbook of Religion and Emotion, edited by John Corrigan, 73-94. Oxford: Oxford University Press.

Hirano Mitsuru, ed. 1983. Kanai hōshin shū [Collection on concerns within the household]. Yasaka Shobō.

Isoda Michifumi. 2013. Kinsei daimyo kashindan no shakai kōzō (The social structure of early modern daimyo retainer bands). Bungei Shunjū. First published by Tōkyō Daigaku Shuppankai, 2003.

Itō Hiroshi. 1973. Taigaku Hirata Atsutane den [Biography of the great teacher Hirata Atsutane]. Kinshōsha.

Kamata Tōji. 200o. "The Disfiguring of Nativism: Hirata Atsutane and Orikuchi Shinobu." In Shinto in History: Ways of the kami, edited by John Breen and Mark Teeuwen, 295-315. Richmond Surry: Curzon Press.

Kitahara-ke monjo. Uncataloged. Kitahara house Zakōji, Iida-shi. Nagano-ken.

Kenuki [Tweezers]. 2012. Kokuritsu gekijo kabuki kanshō kyōshitsu jōen daihon [Performance script from the National theater kabuki appreciation department]. Kokuritsu Gekijo. 
Miyachi Masato, ed. 2005. "Hirata kokugaku no saikentō" [A Reexamination of Hirata national studies] (Part 1), Kokuritsu rekishi minzoku hakubutsukan kenkyū hōkoku, no. 122.

_-_., ed. 2006. "Hirata kokugaku no saikentō" [A Reexamination of Hirata national studies] (Part 2), Kokuritsu rekishi minzoku hakubutsukan kenkyū hōkoku, no. 128.

Nakagawa Kazuaki. 2014. "Hirata Atsutane shokan (Kanetane, O-Chō ate) Tenpō 13.3.14" [Letter from Hirata Atsutane to Kanetane and O-Chō, 1842.3.14]. Suzunoya Gakkai-hō, no. 31: $63-72$.

Nakamura, Sey. 1991. "The Way of the Gods: Motoori Norinaga's Naobi no Mitama," Monumenta Nipponica 46(1): 27-41.

Plamper, Jan. 2010. "The History of Emotions: An Interview with William Reddy, Barbara Rosenwein, and Peter Stearns." History and Theory 49 (May): 237-65.

Rosenwein, Barbara H. 2002. "Worrying about Emotions in History." The American Historical Review 107(3): 821-45.

Shibata Jun. 2013. Nihon yōjishi: Kodomo e no manazashi [A history of the young in Japan: Perspectives on children]. Yoshikawa Kōbunkan.

Shokan (correspondence). Hirata kokugaku kankei shiryō [Archive of materials related to Hirata national studies]. Sakura-shi, National Museum of Japanese History.

Takahashi Satoshi. 1991. "Jūkyū seiki zaigyō machi Kiryū no kazoku to kodomo" [Family and children in the rural town of Kiryū during the nineteenth century]. Explanatory essay in Tenpō-ki, shonen shōjo no kyōiku keisei katei no kenkyū [Research on the process of educational formation for a young boy and a young girl during the Tenpō era, 1830-1844], by Takai Hiroshi, 371-98. Kawade Shobō Shinsha.

Takai Hiroshi. 1991. Tenpō-ki, shonen shōjo no kyōiku keisei katei no kenkyū [Research on the process of educational formation for a young boy and a young girl during the Tenpō era, 1830-1844]. Kawade Shobō Shinsha.

Tamanoi, Mariko Asano. 1991. "Songs as Weapons: The Culture and History of Komori (Nursemaids) in Modern Japan." Journal of Asian Studies 50(4): 793-817.

Ueda Mannen. 1978. Kokugakusha denki shūsei [Collective biography of scholars of national studies]. Vol. 2. Meichō Shukkō Kai.

Uno, Kathleen S. 1987. “Day Care and Family Life in Industrializing Japan, 1868-1926.” PhD diss., University of California, Berkeley.

Walthall, Anne. 1991. “The Life Cycle of Farm Women in Tokugawa Japan." In Recreating Japanese Women, 1600-1945, edited by Gail Lee Bernstein, 42-70. Berkeley: University of California Press.

Watanabe Kinzō. 1942. Hirata Atsutane kenkyū [Research on Hirata Atsutane]. Rokkō Shobō.

Yamaguchi Setsuko. 2014. Mairase soro: Edo-ki, tegami wo nokoshita onnatachi [Women who left correspondence from the Edo period using polite forms of speech]. Asahi Kurie.

Yamazumi Masami and Nakae Kazue. 1983. Kosodate no sho [Books on childraising], no. 2, vol. 176. Heibonsha.

Yokoyama Suzuko, ed. 2012. Hirata Atsutane gosai Orise no Akita kara no tegami shiryōshū [A collection of letters written by Hirata Atsutane's second wife Orise from Akita]. Sakurashi: printed by editor. 
